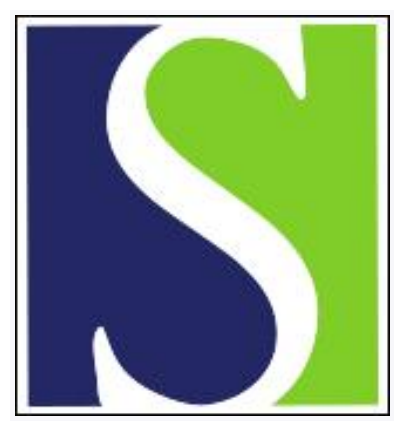

Scand J Work Environ Health 1977;3(4):234-243

https://doi.org/10.5271/sjweh.2775

Issue date: Dec 1977

Acute and repetitive human exposure to isobutane.

by Stewart RD, Herrmann AA, Baretta ED, Forster HV, Sikora JJ, Newton PE, Soto RJ

Key terms: acute human exposure; human response; isobutane; isobutane inhalation; repetition; repetitive human exposure

This article in PubMed: www.ncbi.nlm.nih.gov/pubmed/339337

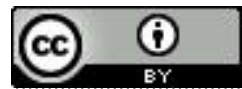




\title{
Acute and repetitive human exposure to isobutane
}

\author{
by RICHARD D. STEWART, M.D., M.P.H., ${ }^{1}$ ANTHONY A. HERRMANN, M.D.,2 \\ EDWARD D. BARETTA, M.Sc., ${ }^{2}$ HUBERT V. FORSTER, Ph.D., ${ }^{1}$ \\ JEANNE J. SIKORA, R.N., ${ }^{2}$ PAUL E. NEWTON, M.Sc., ${ }^{1}$ \\ and RICARDO J. SOTO, M.Sc. ${ }^{2}$
}

\begin{abstract}
STEWART, R. D., HERRMANN, A. A., BARETTA, E. D., FORSTER, H. V., SIKORA, J. J., NEWTON, P. E. and SOTO, R. J. Acute repetitive human exposure to isobutane. Scand. j. work environ. \& health 3 (1977) 234-243. Eight adult volunteers of both sexes were exposed to isobutane in a controlled-environment chamber for the purpose of monitoring their physiological responses to a series of gas concentrations ranging from 250 to $1,000 \mathrm{ppm}$. First, the response to exposure periods of $1 \mathrm{~min}$, $2 \mathrm{~min}, 1 \mathrm{~h}, 2 \mathrm{~h}$, and $8 \mathrm{~h}$ were studied. There being no untoward responses to these acute exposures, the eight volunteers were exposed repetitively to isobutane at concentrations of $500 \mathrm{ppm}, 1,2$ or $8 \mathrm{~h}$ per day, five days per week for two weeks. Then exposures to two mixtures of isobutane and propane for 1,2 or $8 \mathrm{~h}$ per day for two days were studied. During the investigation all subjects were kept under comprehensive medical surveillance. No untoward subjective responses or abnormal physiological responses occurred during or following these exposures. Special emphasis was placed on evaluating the cardiac and pulmonary response to these exposures through the use of continuous ECG telemetry and serial computerized spirometric measurements. The following serial laboratory studies were unaltered by the exposures: complete blood count, urinalysis, serum alkaline phosphatase, SGOT, LDH, serum bilirubin, blood sugar, serum calcium, serum phosphorus, BUN, spontaneous electroencephalogram, visual evoked response, a battery of cognitive tests, and an ACTH stimulation test.
\end{abstract}

Key words: human response, isobutane inhalation.

The increased use of isobutane and propane as substitutes for fluorocarbons in aerosol products raises the question of the potential of these gases to injure humans. The abuse of fluorocarbon propellants and organic solvents to obtain a "high" has resulted in the sudden death of approximately 300 American teenagers, presumably because of epinephrine sensitization of the

1 Department of Environmental Medicine, The Medical College of Wisconsin and the Milwaukee County Medical Complex.

2 Medical Research Center, S. C. Johnson \& Son, Inc., Racine, Wisconsin.

Reprint requests to: Dr. R. D. Stewart, AllenBradley Medical Science Laboratory, 8700 West Wisconsin Avenue, Milwaukee, Wisconsin 53226, U.S.A. heart and the development of fatal cardiac arrhythmia $(2,3,6,7,8,9,12,15,24)$. However, few persons were concerned with the possible health hazard to consumers in normal situations until after Zuskin and Boyhuys suggested that aerosol propellants might be responsible for the transient increase in airway resistance observed after the use of hair sprays (25). Any remaining complacency was shattered by Speizer, Wegman, and Ramirez, who reported that brief exposures to fluorocarbon-22 in the $300 \mathrm{ppm}$ range resulted in the development of severe palpitation in pathology residents in Boston and suggested that exposure to "normal-use" concentrations of certain aerosol propellants might pose health problems not previously recognized (16). 
The paucity of information regarding the human inhalation toxicology of isobutane at concentrations encountered both in home-use situations and in the industrial setting prompted this investigation.

\section{EXPERIMENTAL PROCEDURE}

Eight healthy volunteers of both sexes were exposed to isobutane or a mixture of isobutane and propane in concentrations ranging from those encountered in the home environment to those permitted in the industrial setting (1). First, a series of single exposures to 250,500 , and $1,000 \mathrm{ppm}$ for periods from $1 \mathrm{~min}$ to $8 \mathrm{~h}$ were conducted in a controlled-environment chamber (19). There being no untoward health effects, the subjects were exposed repetitively to $500 \mathrm{ppm}$ of isobutane five days per week for two weeks. Then exposures to two mixtures of isobutane and propane for 1,2 , or $8 \mathrm{~h}$ per day for two days were studied. These experiments were designed so that the absorption, excretion and physiological effect of isobutane inhalation could be studied. Special emphasis was placed on the monitoring of cardiac and pulmonary performance. The exposure schedule is presented in table 1 .

The investigation was performed with strict adherence to the ethical and technical requirements for human inhalation experimentation previously detailed $(17,22)$, and an informed consent was obtained from each subject after the nature of the procedure had been fully explained.

\section{Subjects}

The subjects were selected from the Caucasian, middleclass, college student population. Each subject who completed the study received $\$ 2.50$ per hour spent at the laboratory.

The ages of the four male subjects ranged from 20 to 22 years, height from 178 to $187 \mathrm{~cm}$, and weight from 70.0 to $81.5 \mathrm{~kg}$. None of them was obese. Two of these subjects were assigned to group I (8$\mathrm{h}$ exposure), one to group II (2-h exposure), and one to group III (1-h exposure).

The ages of the four females ranged from 20 to 21 years, height from 155 to 174 $\mathrm{cm}$, and weight from 57.2 to $72.9 \mathrm{~kg}$. The division of the subjects into groups was identical to that for the study with male subjects.

All subjects were cautioned to abstain from the use of drugs and to limit their use of alcohol to very moderate amounts. Subjects who were smokers were not allowed to smoke during their stay in the controlled-environment chamber. Subjects who underwent behavioral testing $(2 \mathrm{~h}$ and $8 \mathrm{~h})$ were asked to refrain from consuming any caffeine prior to the end of each day's study (1-h postexposure).

\section{Exposure schedule}

Table 1 lists the exposure sequence, the number of subjects, the gas concentration investigated, and the duration of each exposure.

\section{Exposure chamber}

The experiments were conducted in a controlled-environment chamber. It had a $6 \times 6 \times 2.4 \mathrm{~m}$ testing room with an attached shielded room and an attached toilet facility. The air flow through the suite of rooms to the exhaust was approximately $42 \mathrm{~m}^{3} / \mathrm{min}$, which created a slight negative pressure within the chamber. The ambient temperature within the chamber was maintained at $22-23^{\circ} \mathrm{C}$, while the relative humidity ranged between $45-55 \%$.

The propellant gas was mixed with the air supplying the chamber, entering through four diffusors in the ceiling of the testing room. For the desired concentration, the gas was metered from a cylinder into the return air duct of the air conditioner.

\section{Analysis of exposure chamber atmosphere}

The gases used in these experiments were purchased from the Phillips Petroleum Company. The isobutane had a boiling point of $-11.73^{\circ} \mathrm{C}$, a vapor pressure of $3,733 \mathrm{~mm} \mathrm{Hg}$ (about $37.7^{\circ} \mathrm{C}$ ), a vapor density of 2.068 (about $15.5^{\circ} \mathrm{C}$ and $60 \mathrm{~mm} \mathrm{Hg}$ ), and a specific gravity of 0.563 (about 15.5/ $\left.15.5^{\circ} \mathrm{C}\right)$.

The propane had a boiling point of $-42.49^{\circ} \mathrm{C}$, a vapor pressure of $6,612 \mathrm{~mm}$ $\mathrm{Hg}$, a vapor density of 1.549 , and a specific gravity of $0.509\left(15.5 / 15.5^{\circ} \mathrm{C}\right)$. 
Table 1. Exposure of human subjects to isobutane and propane.

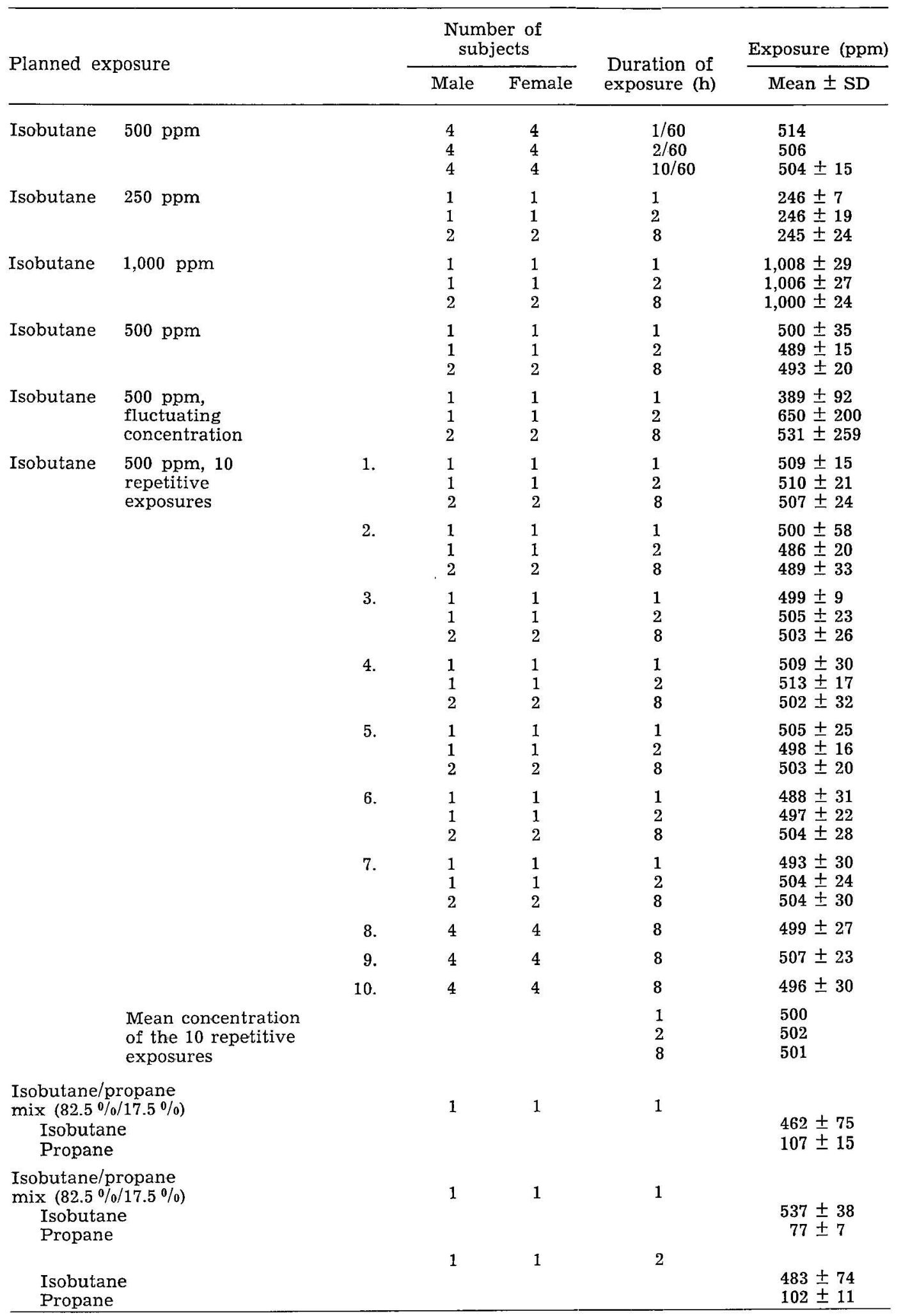




\begin{tabular}{|c|c|c|c|c|}
\hline \multirow{2}{*}{ Planned exposure } & \multicolumn{2}{|c|}{$\begin{array}{l}\text { Number of } \\
\text { subjects }\end{array}$} & \multirow{2}{*}{$\begin{array}{l}\text { Duration of } \\
\text { exposure (h) }\end{array}$} & \multirow{2}{*}{$\frac{\text { Exposure }(\mathrm{ppm})}{\text { Mean } \pm \mathrm{SD}}$} \\
\hline & Male & Female & & \\
\hline $\begin{array}{l}\text { (82\%/17.5 \% mix cont.) } \\
\text { Isobutane } \\
\text { Propane }\end{array}$ & 2 & 2 & 8 & $\begin{array}{l}502 \pm 82 \\
100 \pm 18\end{array}$ \\
\hline $\begin{array}{l}\text { Propane/isobutane } \\
\text { mix }(89 \% / 11 \%) \\
\text { Propane } \\
\text { Isobutane }\end{array}$ & 2 & 2 & 8 & $\begin{array}{l}962 \pm 55 \\
111 \pm 6\end{array}$ \\
\hline $\begin{array}{l}\text { Propane/isobutane } \\
\text { mix }(87.5 \% / 12.5 \%) \\
\text { Propane } \\
\text { Isobutane }\end{array}$ & 2 & 2 & 8 & $\begin{array}{c}1,030 \pm 39 \\
143 \pm 6\end{array}$ \\
\hline
\end{tabular}

Two independent systems were used to monitor the chamber atmosphere. In both cases, air was withdrawn from the chamber through a polyethylene tube (inner diameter $0.64 \mathrm{~cm}$ ) at approximately $7 \mathrm{I} /$ $\mathrm{min}$, through or past the analytical device, to a small diaphragm pump that discharged back into the chamber.

The concentration of the gases in the chamber atmosphere was recorded continuously by a Wilks MIRAN-I infrared spectrometer equipped with a $20-\mathrm{m}$ pathlength gas cell. The absorbance at $3.4 \mu$ was measured. The voltage output was connected to a strip-chart recorder, and a voltage proportional to the pen position of that recorder was conducted to the analog-to-digital input of a PDP-12 (DEC) computer. The computer sampled the pen position voltage each second, averaged those voltages every $30 \mathrm{~s}$, recorded the average on magnetic tape, and used the average to write on a cathode ray tube the concentration over that $30-\mathrm{s}$ interval and the cumulative or time-weighted average concentration since the beginning of the exposure session.

Gas chromatography was the second and the most sensitive method of chamber air analysis employed. A Varian Aerograph Series 2700 gas chromatograph was equipped with a column packed with Porapak Q operated at $87^{\circ} \mathrm{C}$. Nitrogen was used as the carrier gas to a hydrogen flame detector operated at $185^{\circ} \mathrm{C}$. An automatic device injected a sample of air into the gas chromatograph every $170 \mathrm{~s}$. Output of the gas chromatograph was connected to a strip-chart recorder. After each exposure ended, a calibration curve for the obtained values was established with a computer using regression analysis on the standards that had been analyzed during the day. With that equation, peak-height values read manually were transformed into concentrations which were then used to calculate time-weighted averages and standard deviations for exposure increments for comparison with the values obtained using the infrared spectrometer. Concentrations determined by the two methods were in agreement throughout the study.

For the standards, saran bags were filled with room air pumped in sequence through a charcoal column, wet test meter, a Drierite column, and a type $\mathrm{N}$ all-service gas mask canister. After a bag was filled with a known amount of clean, dry air, a known volume of isobutane and/or propane was injected into the bag. For the calibration of the analytical devices the saran bag standard was attached to the sampling probe within the chamber. At least three standards were analyzed before subjects were allowed to enter the chamber each day, and then standards were analyzed at approximately $1-h$ intervals throughout the day.

\section{Clinical testing}

All exposures with a duration of one or more hours were conducted according to a double-blind format. 
Prior to commencing the actual exposures, the subjects underwent a training program in the controlled-environment chamber; during this time they became accustomed to the chamber setting and the testing procedures.

The subjects were given a repeat physical examination prior to each exposure. At this time each of them completed a "symptom checklist." This form had designated spaces for noting the presence of headache; nausea; dizziness; abdominal pain; eye nose, throat irritation; or other subjective symptoms. Each subject reviewed this list of symptoms immediately upon entering the chamber and each hour during and for $5 \mathrm{~h}$ following each exposure. The adjectives "mild, moderate, and strong" appeared on the sheet as cue words, and the phrase "only abnormalities recorded" was prominently typed at the bottom. The home telephone numbers of each of the department physicians appeared on the form, and the subjects were encouraged to phone if they became ill while away from the laboratory.

Prior to and following the exposures, the following laboratory determinations were made: complete blood count, urinalysis, alkaline phosphatase, SGOT, LDH, bilirubin, blood sugar, calcium, phosphorus, BUN. Blood and alveolar breath samples were collected for hydrocarbon gas analysis. The following studies completed the preexposure evaluation: computerized spirometry, 12-lead ECG, and a modified $V_{5}$ ECG rhythm strip by telemetry.

After entering the environmental chamber, the subjects were under continual visual surveillance by medical personnel and all important chamber activities were videotaped by closed circuit. TV. The subjects immediately performed a modified Romberg test followed by a heel-to-toe test. These tests were first performed with the eyes open and then repeated with the eyes closed. Then, each subject completed his subjective symptom checklist as previously discussed. Five minutes prior to exiting from the exposure chamber, each subject repeated the modified Romberg test and the heel-to-toe test. Lead $V_{5}$ telemetry hard copy was obtained from each subject after $30 \mathrm{~min}$ of exposure and hourly thereafter. An additional telemetry strip was obtained each time an ECG change was observed.

During the final $40 \mathrm{~min}$ of exposure subjects exposed for 2 and $8 \mathrm{~h}$ performed the following: computerized spirometry measurements, maximum midexpiratory flow rate, the Flanagan coordination test, the Flanagan arithmetic test, the Marquette time estimation test (21), and the random number inspection test. During the repetitive studies these tests were performed twice a week during the final $2 \mathrm{~h}$ of exposure.

Spontaneous electroencephalograms (EEG) and visual evoked responses (VER) were recorded four times each Monday, Wednesday, and Friday of the two-month period of exposure. All recordings were obtained while the subjects were seated in a comfortable upholstered chair in the shielded room in which the hydrocarbon concentrations were identical to those in the controlled-environment chamber $(11$, 23). The time required to perform the EEG and VER precluded studying more than four subjects per day.

Alveolar breath samples were obtained daily from each subject prior to entry into the environmental chamber, and serially following each exposure. These samples were each collected in 5-l saran bags with the technique previously described in detail $(18,19)$.

Blood samples for hyrocarbon analysis were obtained from an antecubital vein of each subject before exposure, $15 \mathrm{~min}$ before exit from the chamber, and $15 \mathrm{~min}$ after exposure in Vacutainer ${ }^{\circledR}$ tubes with edetic acid anticoagulant. The preexit sample was obtained from the exposed subject's arm after it had been stuck through an armport in the chamber wall into the uncontaminated adjacent laboratory.

\section{Electroencephalography}

Gold-plated silver disk electrodes were oriented on the scalp according to the 1020 International Electrode System (13). The pastefilled disk electrode at the inion was cemented with collodion to the scalp to prevent shifting. An eight channel Grass polygraph fitted with EEG amplifiers was utilized for recording. EEG 
activity was recorded for $15-30 \mathrm{~s}$ before, periodically during, and $15-30 \mathrm{~s}$ after acquisition of the VER. The amplitude, frequency and wave form of the recordings were compared to those of control tracings.

\section{Visual evoked response}

A complete description and illustration of the EEG-VER monitoring system can be found in a previous publication (11). The VER was recorded from the electrode at the inion referred to the left ear. An EEG channel was used to amplify the VER, and the output was fed to an on-line averaging computer (Nicolet, 1074). The VER was triggered by a strobe flash $(3 \mu \mathrm{s})$ at the rate of 1 per second for $128 \mathrm{~s}$. The strobe was operated to deliver 18 million beam candles at $1 \mathrm{~m}$ from the subject's eyes, which were closed throughout the period of strobe flashing. Analysis time was $400 \mathrm{~ms}$. The flash delay from the synchronizing pulse which initiated the computer sweep was $50 \mathrm{~ms}$. The computer averaged the response to the 128 flashes, and the resultant VER was recorded on an X-Y plotter for analysis.

It has been shown that VER amplitude might be altered by varying levels of attention, cortical desynchronization, and sleep $(4,10,14)$. Accordingly, standardized conditions were used throughout each exposure day and immediately preceding the actual recordings. A rigid schedule for food intake, physical activity, and additional testing procedures was followed. In addition, after entering the booth, the subject was always allowed $3-5 \mathrm{~min}$ to achieve a relaxed state; and then immediately prior to initiating the strobe flash, the subject was asked to clap his hands five times slowly and forcibly to insure a wakeful, attentive state.

The most prominent reproducible portions of the VER complex are the third, fourth, and fifth waves (designation by Gastaut) $(5,10,11)$. The analysis was thus restricted to these waves. Wave 3 was identified as proceeding in a positive direction $80-120 \mathrm{~ms}$ after the initiation of the strobe flash. Waves 4 and 5 were the succeeding negative and positive segments of the VER. Analysis involved: (a) measuring the amplitude of these waves and (b) measuring whether changes had occurred in the latency and wave form of the VER complex.

\section{Adrenocortical function}

Upon the completion of the repetitive exposures the subjects underwent the standard 2-day ACTH stimulation test for the assessment of the ability of the adrenal gland to respond to stress. The reason for this testing was the observation that the organ with the highest hydrocarbon concentration following exposure is the adrenal cortex.

\section{Analysis of ambient air, expired breath and blood}

Air and breath samples for hydrocarbon analysis were injected directly onto a Porapak Q column of a Varian Aerograph Series 2700 gas chromatograph equipped with a hydrogen flame ionization detector. The column and operating conditions were: column: $45.72 \mathrm{~cm} \times 0.32$ cm O.D. stainless steel; column packing: Porapak Q, 50-80 mesh; oven temperature: $87^{\circ} \mathrm{C}$; injector temperature: $150^{\circ} \mathrm{C}$; detector temperature: $185^{\circ} \mathrm{C}$; carrier gas: nitrogen, $20 \mathrm{ml} / \mathrm{min}$.

Air standards were prepared by direct injection of the appropriate quantity of isobutane or propane into a saran bag containing a measured volume of air.

A headspace sampling technique was utilized for measuring the concentration of the hydrocarbons in blood. Blood standards were prepared by the direct addition of an appropriate quantity of an air standard containing $1,000 \mathrm{ppm}$ propane or isobutane to a Vacutainer tube containing a known quantity of blood. The freshly drawn anticoagulated blood sample was allowed to equilibrate with the hydrocarbon by agitation. The headspace sample was injected directly into a gas chromatograph for analysis. The technique was far superior to the solvent extraction methods used previously.

\section{Medical surveillance}

The subjects were under continuous visual surveillance by a physician and by nursing personnel during each exposure. The pre- 
exposure physical examinations and clinical laboratory determinations were obtained according to the schedule previously detailed.

All subjects were placed under close medical surveillance following each exposure. A resting 12-lead ECG was obtained 15-30 min after exposure. All of the preexposure clinical studies were repeated on a weekly basis, and the subjects were kept under surveillance for one year following these exposures.

Following the last exposure of the sequence, each subject was given a comprehensive medical examination including a complete history and physical examination with the following laboratory studies: complete blood count, urinalysis, complete panel of clinical chemistries (23 values plus 2 calculated), and a 12-lead ECG. Then the health of each subject was monitored for one year by the investigators.

\section{RESULTS}

\section{Analysis of exposure chamber atmosphere}

The daily time-weighted average concentrations of isobutane or propane in the controlled-environment chamber for each of the exposure conditions are found in table 1 . The actual concentrations were within a few per cent of those desired.

\section{Medical surveillance}

No untoward subjective symptoms or objective signs of illness were noted dur- ing exposure or in the surveillance period which followed each exposure. Pre- and postexposure comprehensive medical examinations revealed that all subjects remained in good health during the study (20). All of the clinical hematologies and chemistries remained within the limits of normal (20). When a laboratory measurement varied more than two standard deviations from the normal mean value (5\% of all measurements), a repeat determination was obtained to confirm that a significant change had not occurred.

Isobutane was present in the blood and expired breath of the subjects during and following exposure (20). The isobutane blood levels are listed in table 2. The isobutane breath data have been presented elsewhere (20).

\section{Effects of exposure on the heart}

None of the subjects experienced any untoward signs or symptoms referable to the heart during exposure or in the postexposure period of surveillance. No change from the preexposure control ECG tracing was observed in the postexposure standard 12-lead ECGs or in the modified lead $\mathrm{V}_{5}$ monitored continuously by telemetry during the different exposures. None of the subjects developed arrhythmia.

\section{Pulmonary function studies}

The functional integrity of the pulmonary airways, as monitored by the pulmonary function tests, did not appear to be affected by either the acute or the repetitive series of exposures (20). A summary of the spirometric data is listed in table 3.

Table 2. Isobutane in blood, micrograms per milliliter, during and following repetitive 8-h exposures to an isobutane concentration of $500 \mathrm{ppm}$. (Mean \pm standard deviation)

\begin{tabular}{|c|c|c|c|c|c|c|c|c|}
\hline \multirow{2}{*}{ Time } & \multicolumn{3}{|c|}{ First Week } & \multicolumn{3}{|c|}{ Second Week } & \multirow{2}{*}{$\begin{array}{l}500 \mathrm{ppm} \\
\text { fluctuating }\end{array}$} & \multirow{2}{*}{$\begin{array}{l}\text { All } 500 \text { ppm } \\
\text { exposures }\end{array}$} \\
\hline & Mon. & Wed. & Fri. & Mon. & Wed. & Fri. & & \\
\hline Preexposure & $\begin{array}{r}0.00 \\
\pm 0.00\end{array}$ & $\begin{array}{r}0.01 \\
\pm 0.00\end{array}$ & $\begin{array}{r}0.01 \\
\pm 0.00\end{array}$ & $\begin{array}{r}0.00 \\
+0.00\end{array}$ & $\begin{array}{r}0.01 \\
\pm 0.00\end{array}$ & $\begin{array}{r}0.01 \\
\pm 0.00\end{array}$ & $0.01 \pm 0.01$ & $0.01 \pm 0.00$ \\
\hline $\begin{array}{l}15 \text { min } \\
\text { preexit }\end{array}$ & $\begin{array}{r}0.08 \\
\pm 0.01\end{array}$ & $\begin{array}{r}0.06 \\
\pm 0.01\end{array}$ & $\begin{array}{r}0.07 \\
\pm 0.02\end{array}$ & $\begin{array}{r}0.08 \\
\pm 0.02\end{array}$ & $\begin{array}{r}0.07 \\
\pm 0.02\end{array}$ & $\begin{array}{r}0.05 \\
+0.01\end{array}$ & $0.09 \pm 0.03$ & $0.07 \pm 0.01$ \\
\hline $\begin{array}{l}15 \mathrm{~min} \\
\text { postexit }\end{array}$ & $\begin{array}{r}0.02 \\
\pm 0.01\end{array}$ & $\begin{array}{r}0.02 \\
\pm 0.01\end{array}$ & $\begin{array}{r}0.02 \\
\pm 0.00\end{array}$ & $\begin{array}{r}0.02 \\
+0.01\end{array}$ & $\begin{array}{r}0.02 \\
\pm 0.01\end{array}$ & $\begin{array}{r}0.02 \\
\pm \quad 0.01\end{array}$ & $0.03 \pm 0.01$ & $0.02 \pm 0.00$ \\
\hline
\end{tabular}


Table 3. Pulmonary function after $5 \mathrm{~h}$ of exposure to isobutane. ${ }^{\mathrm{a}}$ (Mean \pm standard deviation)

\begin{tabular}{|c|c|c|c|c|}
\hline \multirow{2}{*}{ Condition } & \multirow{2}{*}{$\begin{array}{c}\text { FVC } \\
\text { (1 BTPs) }\end{array}$} & $\mathrm{FEV}_{1} \%$ & \multirow{2}{*}{$\begin{array}{c}\text { PEFR } \\
(1 / s)\end{array}$} & \multirow{2}{*}{$\underset{(1 / \mathrm{s})}{\operatorname{MMEF}}$} \\
\hline & & FVC & & \\
\hline \multicolumn{5}{|l|}{$\begin{array}{l}\text { Repetitive exposure, } \\
500 \text { ppm, } \mathrm{n}=4\end{array}$} \\
\hline $\begin{array}{l}\text { Control } \\
\text { 1st day, 1st week } \\
\text { 3rd day, 1st week } \\
\text { 2nd day, 2nd week } \\
\text { 5th day, 2nd week }\end{array}$ & $\begin{array}{l}4.3 \pm 1 \\
4.4 \pm 1.2 \\
4.3 \pm 1.3 \\
4.3 \pm 1.2 \\
4.5 \pm 1.2\end{array}$ & $\begin{array}{l}87.6 \pm 3.5 \\
85.6 \pm 7.7 \\
88.7 \pm 7.4 \\
86.8 \pm 6.3 \\
83.9 \pm 4.9\end{array}$ & $\begin{array}{l}9.4 \pm 2.6 \\
8.8 \pm 2.5 \\
8.7 \pm 2.7 \\
8.6 \pm 2.5 \\
8.4 \pm 2.3\end{array}$ & $\begin{array}{l}4.7 \pm 1.2 \\
4.5 \pm 0.5 \\
4.7 \pm 0.3 \\
4.4 \pm 0.2 \\
4.5 \pm 0.4\end{array}$ \\
\hline \multicolumn{5}{|l|}{$\begin{array}{l}\text { Single exposure, } \\
1,000 \text { ppm, } \mathrm{n}=3\end{array}$} \\
\hline $\begin{array}{l}\text { Control } \\
\text { Single exposure }\end{array}$ & $\begin{array}{l}4.1 \pm 1.0 \\
4.2 \pm 1\end{array}$ & $\begin{array}{l}85.6 \pm 5.5 \\
85.2 \pm 4.4\end{array}$ & $\begin{array}{l}8.7 \pm 1.9 \\
8.6 \pm 1.7\end{array}$ & $\begin{array}{l}4.2 \pm 0.3 \\
4.1 \pm 0.7\end{array}$ \\
\hline
\end{tabular}

a $\quad$ FVC $=$ maximum volume of air exhaled after a maximum inspiration; $\mathrm{FEV}_{1} / \mathrm{FVC}=$ per cent of FVC exhaled in $1 \mathrm{~s}$; PEFR = maximum rate of air flow during FVC maneuver; MMEF = maximum rate of air flow at midpoint of FVC.

Table 4. Eight-hour ACTH stimulation test following repetitive exposures to isobutane.

\begin{tabular}{|c|c|c|c|c|c|c|c|c|c|c|}
\hline \multirow[t]{2}{*}{ Subject } & \multicolumn{2}{|c|}{$\begin{array}{l}\text { Preexposure } \\
\text { control } \\
24-\mathrm{h} \text { urine }\end{array}$} & \multicolumn{2}{|c|}{$\begin{array}{c}\text { After } 5 \\
\text { repetitive } \\
\text { 8-h exposures }\end{array}$} & \multicolumn{2}{|c|}{$\begin{array}{l}\text { After } 10 \\
\text { repetitive } \\
\text { 8-h exposures }\end{array}$} & \multicolumn{2}{|c|}{$\begin{array}{c}\text { 1st day of } \\
\text { ACTH }\end{array}$} & \multicolumn{2}{|c|}{$\begin{array}{l}\text { 2nd day of } \\
\text { ACTH }\end{array}$} \\
\hline & $\begin{array}{c}17-\mathrm{KS} \\
(\mathrm{mg})\end{array}$ & $\begin{array}{c}\text { 17-OH } \\
(\mathrm{mg})\end{array}$ & $\begin{array}{c}\text { 17-KS } \\
(\mathrm{mg})\end{array}$ & $\begin{array}{c}\text { 17-OH } \\
(\mathrm{mg})\end{array}$ & $\begin{array}{c}\text { 17-KS } \\
\text { (mg) }\end{array}$ & $\begin{array}{c}17-\mathrm{OH} \\
(\mathrm{mg})\end{array}$ & $\begin{array}{c}17-\mathrm{KS} \\
\text { (mg) }\end{array}$ & $\begin{array}{c}17-\mathrm{OH} \\
(\mathrm{mg})\end{array}$ & $\begin{array}{c}\text { 17-KS } \\
\text { (mg) }\end{array}$ & $\begin{array}{c}17-\mathrm{OH} \\
(\mathrm{mg})\end{array}$ \\
\hline Male & 13.3 & 7.7 & 14.1 & 8.6 & 20.5 & 6.6 & 22.3 & 26.4 & 26.5 & 40.1 \\
\hline Male & 14.6 & 8.2 & 15.7 & 4.5 & 16.3 & 10.2 & 24.7 & 46.3 & 31.2 & 65.7 \\
\hline Female & 7.1 & 3.9 & 6.9 & 4.0 & No sa & ample & 13.7 & 15.6 & 18.1 & 28.7 \\
\hline Female & 11.4 & 5.1 & 7.1 & 5.0 & 12.8 & 6.6 & 15.6 & 20.1 & 16.2 & 33.2 \\
\hline
\end{tabular}

No trends or consistent changes were noted.

\section{Adrenocorticotrophic hormone stimulation test}

Following the repetitive exposures, all eight subjects had normal 17-ketosteroids and 17-hydroxyketosteroids. The subjects were given an 8-h ACTH stimulation test (40 units) on two successive days, and all showed a normal response (table 4).

\section{Neurological studies}

No neurological abnormalities occurred during the observation period. The modified Romberg test and the heel-to-toe test remained normal. The routine neuro- logical test was unaltered by the exposures.

\section{Electroencephalography}

No significant alterations occurred in the EEGs of any of the subjects under any of the exposure conditions (20). Time constraints precluded the obtaining of a complete EEG, and thus limited the value of these data.

\section{Visual evoked response}

During the final week of exposure a definite reduction in the amplitudes of the 3,4 , and 5 waves was observed. The significance of this observation is uncertain and merits further investigation. 


\section{Cognitive tests}

Exposure to isobutane, or mixtures of isobutane and propane, did not result in cognitive test performance decrements (20). The mean test performances under control and exposure conditions were plotted for each control and exposure day. Then a linear regression line with $75 \%$ confidence limits was drawn through the 0 ppm data. After adjustment for the trend through the $0 \mathrm{ppm}$ data, $t$ tests were performed to determine if the exposure data were significantly different from the regression line.

On two occasions arithmetic scores were higher than anticipated, but in the absence of a consistent change in test performance or a dose-related response, these results are interpreted as showing no effect of exposure.

\section{DISCUSSION}

Acute exposures to isobutane in concentrations of 250,500 , or $1,000 \mathrm{ppm}$ for periods of $1 \mathrm{~min}$ to $8 \mathrm{~h}$ did not produce any untoward physiological effect as monitored by the methods employed. Repetitive exposures to isobutane $500 \mathrm{ppm}$ for 1,2 or $8 \mathrm{~h}$, five days a week for ten exposures were also without any measurable untoward physiological effect. Mixtures of the two gases in the concentrations investigated exerted no untoward physiological effects.

Of particular importance was the observation that none of the subjects showed any decrement in pulmonary function or alteration in cardiac rhythm as the resuit of exposure to concentrations of the gases permitted in the occupational setting, concentrations generally higher and of much greater duration than would occur during the normal use of aerosol products in the home. Thus it would seem that short-term exposure to isobutane not exceeding the threshold limit value for American industry does not have the potential to affect normal heart or lungs adversely.

The reduction in the VER wave amplitude recorded during the second week of repetitive exposure to isobutane is troublesome because this type of reduction can be due to central nervous depression and has been observed prior to the development of overt signs of neurological impairment (23). This finding merits further investigation.

The analysis of expired breath or blood for isobutane in the early postexposure period provides a feasible diagnostic test of exposure. The use of gas chromatography permits the detection of isobutane in expired breath for at least $5 \mathrm{~h}$ after two or more hours of exposure.

\section{ACKNOWLEDGMENTS}

This investigation was supported in part from funds collected by the Ad Hoc Aerosol Committee, representatives of major trade associations and industrial companies with interests in aerosol safety.

The expertise of Michael J. Hosko, Ph.D., Department of Pharmacology, and Gregory J. Harrington, M.D., Department of Neurology, in reviewing and interpreting the electroencephalograms and visual evoked response measurements is gratefully acknowledged. The authors thank the members of the task force of the Inter-Industry Aerosol Safety Committee for their many helpful suggestions and their review of the manuscript.

\section{REFERENCES}

1. AMERICAN CONFERENCE OF GOVERNMENTAL INDUSTRIAL HYGIENISTS. Threshold limit values for substances in workroom air adopted by ACGIH for 1976. Cincinnati, Ohio, 1976.

2. AZAR, A., ZAPP, J. A., REINHARDT, C. F. and STOPPS, G. J. Cardiac toxicity of aerosol propellants. J. am. med. assoc. 215 (1971) 1501-1502.

3. BASS, M. Sudden sniffing death. J. am. med. assoc. 212 (1970) 2075-2079.

4. BERGAMASCO, B. Excitability cycle of the visual cortex in normal subjects during psychosensory rest and cardiozolic activation. Brain res. 2 (1966) 51-60.

5. CIGANEK, L. A comparative study of visual, auditory, and comatosensory EEG responses in man. Exp. brain res. 4 (1967) $118-125$.

6. CLARK, D. G. and TINSTON, D. J. Sniffing syndrome. Br. med. j., 2 (1971) 113 114.

7. CLARK, D. G. and TINSTON, D. J. Cardiac effects of isoproterenol, hypoxia, hypercapnia and fluorocarbon propellants 
and their use in asthma inhalers. Ann. allergy 30 (1972) $536-541$.

8. CLARK, D. G. and TINSTON, D. The influence of fluorocarbon propellants on the arrhythmogenic activities of adrenaline and isoprenaline in conscious dogs. Proc. eur. soc. study drug toxic. 13 (1972) 212217.

9. EDITORIAL. Cardiac toxicity of aerosol propellants. J. am. med. assoc. 214 (1970) 136.

10. GASTAUT, H. and REGIS, H. Visually evoked potentials recorded transcranially in man. In: L. D. PROCTOR, and W. R. ADEZ (eds.), Symposium on the analysis of CNS and CU data using computer methods, (NASA publication no. SP-72), Washington, D.C. 1964, pp. 7-34.

11. HOSKO, M. J. Effect of carbon monoxide exposure on the spontaneous electroencephalogram and the visual evoked response in man. Arch. environ. health 21 (1970) $174-180$.

12. JACK, D. Sniffing syndrome. Br. med. $j$. 2 (1971) 708-709.

13. JASPER, $H$. $H$. The $10-20$ electrode systems of the international federation. Electroencephalogr. clin. neurophysiol. 10 (1958) $371-375$.

14. PERRY, N. W. and CHILDERS, D. G. The human visual evoked response. C. C. Thomas, Springfield, Ill. 1969, pp. 49-69.

15. REINHARDT, C. F., AZAR, A., MAXFIELD, IM. E., SMITH, P. E. and MULLIN, L. S. Cardiac arrhythmias and aerosol 'sniffing.' Arch. environ. health 22 (1971) $265-279$

16. SPEIZER, F. E., WEGMAN, D. H. and RAMIREZ, A. Palpitation rates associated with fluorocarbon exposure in hospital setting. $N$. engl. j. med. 292 (1975) 624-626.

17. STEWART, R. D. Use of human volunteers for the toxicological evaluation of materials. In: NATIONAL ACADEMY OF SCIENCES, Symposium on an appraisal of halogenated fire extinguishing agents. Washington, D.C. 1972.

18. STEWART, R. D. The use of breath aralysis in clinical toxicology. In: W HAYES (ed.), Essays in toxicology (vol. V, chapter 5). Academic Press, New York, N.Y. 1974, pp. $121-147$.

19. STEWART, R. D., HAKE, C. L. and WU, A. Use of breath analysis to monitor methylene chloride exposure. Scand. j. work environ. \& health 2 (1976) 57-70.

20. STEWART, R. D., HERRMANN, A. A., BARETTA, E. D., FORSTER, H. V., SIKORA, J. J., NEWTON, P. E. and SOTO, R. J. Acute and repetitive human exposure to isobutane and propane (Report no. IASSCTFA-MCOW-ENVM-BP-77-1, April, 1977). National Clearinghouse for Federal Scientific and Technical Information, Springfield, Va. 1977.

21. STEWART, R. D., NEWTON, P. E., HOSKO, M. J. and PETERSON, J. E. Effect of carbon monoxide on time perception. Arch. environ. health, 27 (1973) 155160.

22. STEWART, R. D., PETERSON, J. E., HAKE, C. L., LEBRUN, A. J. and NEWTON, P. E. Measurement of physiological and behavioral responses in a controlledenvironment chamber. In: C. XINTARAS, B. L. JOHNSON and I. DE GROOT (eds.), Behavioral toxicology: Early detection of occupational hazards (HEW publication no. (NIOSH) $74-126)$. 1974 , pp. $361-375$.

23. STEWART, R. D., PETERSON, J. E., NEWTON, P. E., HAKE, C. L., HOSKO, M. J., LEBRUN, A. J. and LAWTON, G. M. Experimental human exposure to propylene glycol dinitrate. Toxicol. appl. pharmacol. 30 (1974) 377-395.

24. TAYLOR, G. J. and HARRIS, W. S. Cardiac toxicity of aerosol propellants. $J$. am. med. assoc. 214 (1970) 81-85.

25. ZUSKIN, E. and BOUHUYS, A. Acute airway responses to hair-spray preparations. N. eng. j. med. 290 (1974) $660-663$.

Received for publication: 1977-08-09 